\title{
Ten things to get right for marine conservation planning in
}

\section{the Coral Triangle [version 1; peer review: 1 approved, 1}

\section{approved with reservations]}

\author{
Rebecca Weeks ${ }^{1}$, Robert L. Pressey ${ }^{1}$, Joanne R. Wilson ${ }^{2}$, Maurice Knight ${ }^{1}{ }^{1}$, \\ Vera Horigue ${ }^{1}$, Rene A. Abesamis ${ }^{4}$, Renerio Acosta5, Jamaluddin Jompa 6 \\ ${ }^{1}$ Australian Research Council Centre of Excellence for Coral Reef Studies, James Cook University, Townsville, Australia \\ ${ }^{2}$ Sea Solutions, Pottsville, Australia \\ ${ }^{3}$ USAID Coral Triangle Support Partnership, Jakarta, Indonesia \\ ${ }^{4}$ Silliman University Angelo King Center for Research and Environmental Management, Dumaguete, Philippines \\ 5 USAID Regional Development Mission for Asia, Bangkok, Thailand \\ ${ }^{6}$ Department of Marine Science, Hasanuddin University, Makassar, Indonesia
}

V1 First published: 17 Apr 2014, 3:91

https://doi.org/10.12688/f1000research.3886.1

Second version: 11 Jun 2014, 3:91

https://doi.org/10.12688/f1000research.3886.2

Latest published: 21 Dec 2015, 3:91

https://doi.org/10.12688/f1000research.3886.3

\section{Abstract}

Systematic conservation planning increasingly underpins the conservation and management of marine and coastal ecosystems worldwide. Amongst other benefits, conservation planning provides transparency in decision-making, efficiency in the use of limited resources, the ability to minimise conflict between diverse objectives, and to guide strategic expansion of local actions to maximise their cumulative impact. The Coral Triangle has long been recognised as a global marine conservation priority, and has been the subject of huge investment in conservation during the last five years through the Coral Triangle Initiative on Coral Reefs, Fisheries and Food Security. Yet conservation planning has had relatively little influence in this region. To explore why this is the case, we identify and discuss 10 challenges that must be resolved if conservation planning is to effectively inform management actions in the Coral Triangle. These are: making conservation planning accessible; integrating with other planning processes; building local capacity for conservation planning; institutionalising conservation planning within governments; integrating plans across governance levels; planning across governance boundaries; planning for multiple tools and objectives; understanding limitations of data; developing better measures of progress and effectiveness; and making a long term commitment. Most important is a conceptual shift from conservation planning undertaken as a project, to planning undertaken as a process, with dedicated financial and human resources committed to long-term

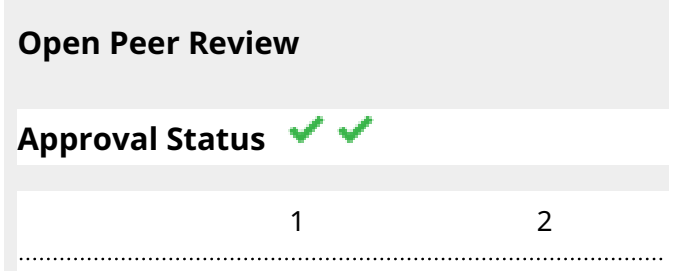

version 3

(revision)

21 Dec 2015

version 2

(revision)

11 Jun 2014

version 1

17 Apr 2014

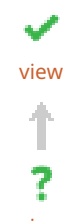

1. Helen Yap ID, University of the Philippines,

Quezon City, Philippines

2. Pedro Fidelman, University of the Sunshine

Coast, Sunshine Coast, QId, Australia

Any reports and responses or comments on the article can be found at the end of the article. 
engagement.

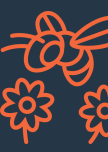

This article is included in the Ecology and

Global Change gateway.

Corresponding author: Rebecca Weeks (Rebecca.weeks@jcu.edu.au)

Competing interests: No competing interests were disclosed.

Grant information: The focus group from which this manuscript originated was made possible by funding support from the Australian Research Council provided to RLP. RW, RLP and VH acknowledge the Australian Research Council for funding support. The participation of MK and RA was made possible by the generous support of the American people through the United States Agency for International Development (USAID). The contents are the responsibility of the authors and do not necessarily reflect the views of USAID or the United States Government.

The funders had no role in study design, data collection and analysis, decision to publish, or preparation of the manuscript.

Copyright: $\odot 2014$ Weeks R et al. This is an open access article distributed under the terms of the Creative Commons Attribution License, which permits unrestricted use, distribution, and reproduction in any medium, provided the original work is properly cited. Data associated with the article are available under the terms of the Creative Commons Zero "No rights reserved" data waiver (CCO 1.0 Public domain dedication).

How to cite this article: Weeks R, Pressey RL, Wilson JR et al. Ten things to get right for marine conservation planning in the Coral Triangle [version 1; peer review: 1 approved, 1 approved with reservations] F1000Research 2014, 3:91

https://doi.org/10.12688/f1000research.3886.1

First published: 17 Apr 2014, 3:91 https://doi.org/10.12688/f1000research.3886.1 


\section{Introduction}

The Coral Triangle, which encompasses the marine waters of Indonesia, Malaysia, Papua New Guinea, Philippines, Solomon Islands, and Timor-Leste, is the epicentre of marine biodiversity and widely recognised as a global conservation priority ${ }^{1}$. In addition to their conservation value, the Coral Triangle's marine resources are a cornerstone of the region's economies and societies, with millions of people dependent upon them as a daily source of food and income $^{2}$. The health of these ecosystems is at severe risk due to destructive and over-fishing, coastal development, poor water quality, and climate change ${ }^{3}$.

In 2009, the six Coral Triangle countries, supported by USAID and other external funders, embarked upon the Coral Triangle Initiative on Coral Reefs, Fisheries and Food Security (CTI-CFF), an unprecedented multilateral partnership to address threats to the region's marine and coastal resources through accelerated and collaborative action. The CTI-CFF goals include the designation of priority seascapes, establishment of a Coral Triangle marine protected area (MPA) system, the protection of threatened species, coordinated action on climate adaptation, and implementation of an ecosystem approach to fisheries management ${ }^{4}$. As the initial five-year phase of the CTI-CFF came to a close in 2013, much has been accomplished, but much work remains if these goals are to be achieved ${ }^{5}$.

Marine conservation planning is a systematic approach to developing spatial plans, primarily focused on conservation of biodiversity, habitats and ecological processes, while facilitating multiple uses of the marine environment and promoting, where possible, goals related to climate change, fisheries, and livelihoods. In the last three decades, conservation planning has evolved from an academic discipline to have considerable influence on conservation action around the world ${ }^{6}$. Yet, systematic approaches have had relatively little influence on conservation in the Coral Triangle - one region where they are needed most.

Conservation planning provides benefits at both regional and local scales. Regional-scale planning is critical for achieving objectives that require broad perspectives and emergent properties ${ }^{7}$ that mean the whole (e.g. a system of MPAs) is greater than the sum of the parts (individual MPAs). Emergent properties are achieved through, for example, complementarity of ecosystems and species and connectivity between individual MPAs ${ }^{8,9}$. Systematic planning provides a transparent framework to ensure efficient use of limited resources, and offers a proactive alternative to reactive actions in the face of increasing threats to natural resources ${ }^{10,11}$. Importantly, systematic planning can be used to minimise conflict between conservation goals and the diverse aspirations of users of the marine environment ${ }^{12,13}$.

The Coral Triangle has experienced rapid growth in the number of individual MPAs designated or initiated primarily by communities and local governments. Yet, despite the many benefits of local and community-led actions, few MPAs are effectively managed ${ }^{14}$ and, without coordination, they often fail to form functional conservation networks that achieve regional-scale objectives ${ }^{15-17}$. Systematic planning can inform strategic expansion of local actions to maximise their cumulative contribution towards regional-scale goals ${ }^{18,19}$, including the broad goals of the CTI-CFF.
Systematic conservation planning in the Coral Triangle faces particular challenges. With the first phase of the CTI-CFF now complete, it is timely to explore these challenges and how they might be overcome. To do so, we convened a focus group of conservation biologists, practitioners, policy makers, and donors working in the region (the authors). We first outlined a vision: of conservation planning applied throughout the Coral Triangle, at spatial scales ranging from local to region-wide, to effectively inform management actions implemented to achieve objectives for biodiversity, fisheries, and food security. We then considered constraints on this vision being realised, and sought to identify strategies to overcome the constraints.

From an initial list of "things to get right", we consolidated related topics, and excluded those that we considered either trivial or overly specific, to arrive at the final 10 (Table 1). The topics that we discuss here are deliberately ambitious, and we do not claim either a complete analysis of these challenges or to provide solutions. Our aim is to highlight issues that have not been widely approached or discussed in the literature, which has focused primarily on technical aspects of MPA network design e.g. ${ }^{20}$. We acknowledge that the context for, and approaches to, conservation planning vary widely throughout the Coral Triangle. While some of the strategies we propose are being applied to some extent in parts of the region, and we highlight examples of these, without exception they are not being addressed effectively or extensively enough in the Coral Triangle, or indeed in many other regions. The overall goal of this paper is to contribute to the evolving agenda for marine conservation planning in the Coral Triangle by stimulating dialogue about these important and neglected topics.

\section{Things to get right}

For each of our 10 topics (summarised in Table 1), we first outline a problem statement, and then suggest potential ways forward.

\section{Making conservation planning accessible}

Historically, marine conservation planning in the Coral Triangle has typically been initiated and led by non-government organisations (NGOs) or academia, often through collaboration with local communities or governments ${ }^{18,21-23}$. These planning initiatives, although valuable in demonstrating concepts, analyses and, at limited scales, applications to on-ground actions, have inevitably focused on specific areas within the Coral Triangle that constitute a very small proportion of the entire region. To achieve wider application of marine conservation planning, the established and emerging approaches and tools need to be made more accessible to a much wider range of practitioners, including those in government agencies responsible for spatial planning at levels from local to national.

Beyond a lack of local capacity to implement conservation planning methods (see section 3), there exists a lack of awareness of what conservation planning is and why it is needed, among people responsible for managing coastal and marine resources. In the past, the dominance of developed countries in generating research on conservation planning biased approaches toward extensive prioritizations and, where these are actually applied, toward simple governance contexts ${ }^{7}$. These biases led to earlier misconceptions amongst policy-makers and potential practitioners in developing countries 


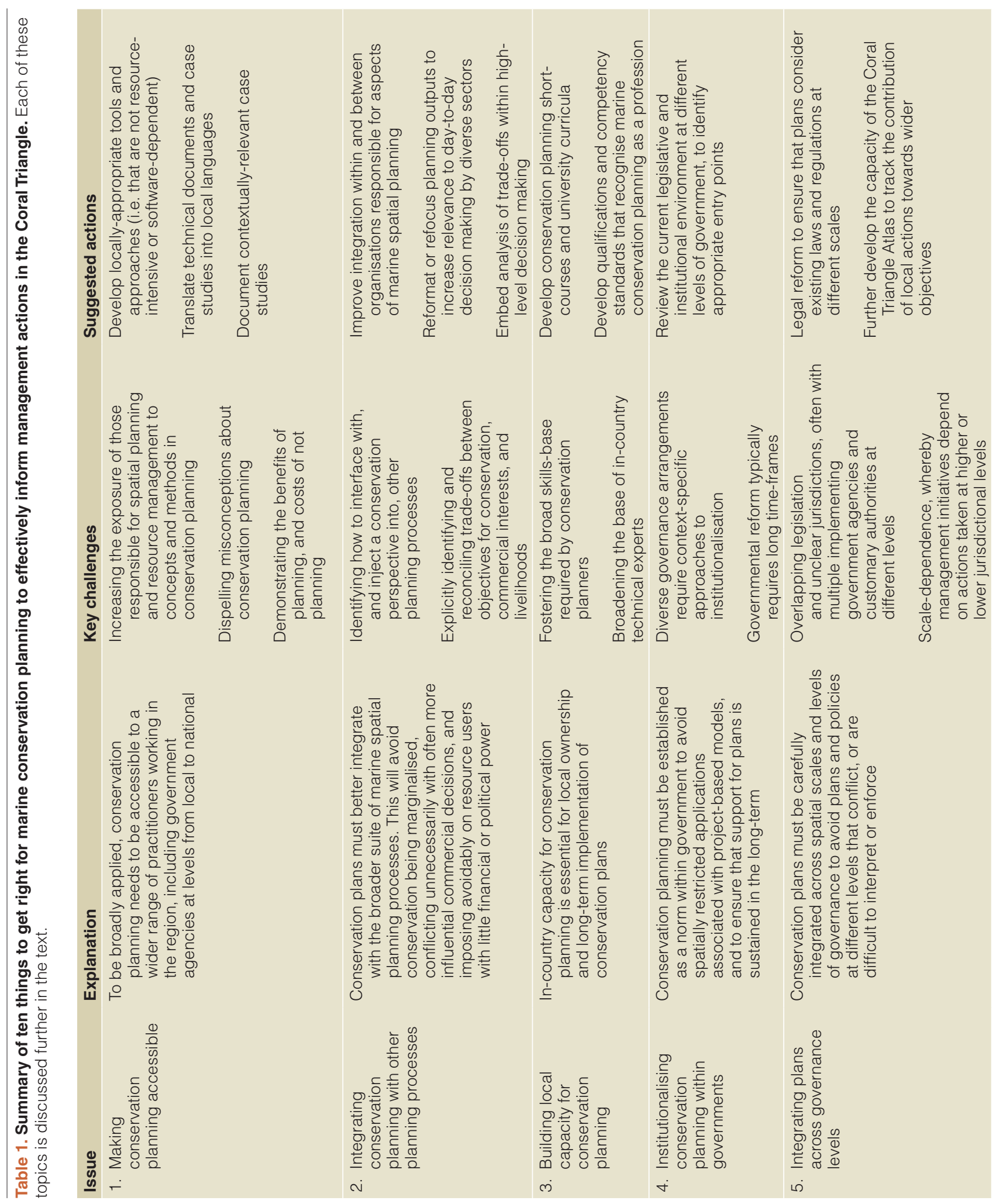




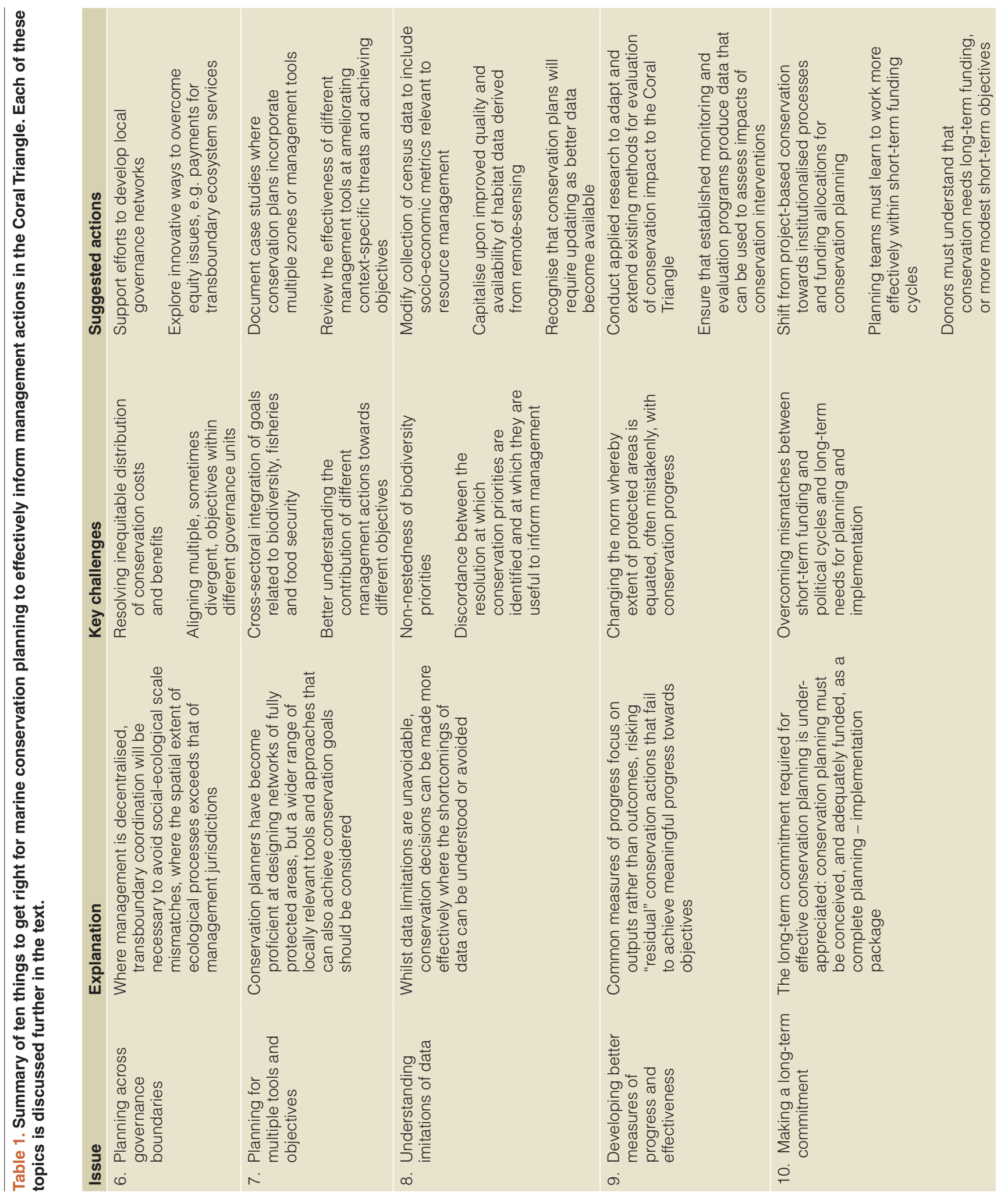


that conservation planning is only relevant to top-down, centralised planning ${ }^{24}$, that it is incapable of dealing with the social, economic, and cultural complexities of the Coral Triangle ${ }^{25}$, and that planning processes depend upon the use of decision-support software and data of a quality and quantity that are generally unavailable in the region. The CTI-CFF has helped to reduce these misconceptions and recognise the importance of combining bottom-up and topdown engagement to achieve goals for conservation planning. For example, the Solomon Islands and Timor-Leste have embraced and allocated funding for community-based planning as the foundation of their national approaches (personal communication: R. Pinto, Conservation International Timor-Leste; A. Vavekaramui, Solomon Islands Ministry of Environment, Meteorology, Disaster Response and Climate Change). However, systematic conservation planning is still largely a peripheral and under-valued activity in the overall operations of government organisations.

Making conservation planning accessible requires increasing the exposure of those responsible for spatial planning and coastal resource management to conservation planning concepts and processes, and at the same time dispelling misconceptions that might have developed from limited information.

Much that is written about conservation planning appears in literature that is inaccessible to potential users in the Coral Triangle. A learning study conducted at the end of the five-year USAID Coral Triangle Support Partnership program ${ }^{26}$ revealed that, among those surveyed, 54\% never or rarely used the 265 separate knowledge products produced, and only $20 \%$ frequently or often used them. These products included position papers, books, training manuals, field guidance manuals and other materials produce by the USAID Coral Triangle Support Partnership, the US National Oceanic and Atmospheric Administration and the US CTI Support Program Integrator based in Bangkok. Poor uptake is likely due to lack of awareness of recently produced materials, and the need for more simplified materials for some applications. This clearly shows that coastal resource management practitioners in the Coral Triangle are in a nascent stage with respect to accessing literature and knowledge products supporting conservation planning.

A broader, more accurate awareness of conservation planning will be achieved by encouraging researchers to publish in open-access journals ${ }^{27}$, translating technical documents and case studies into local languages, and distributing presentations and documents through peer-learning networks (e.g. the Philippine MPA Support Network). Knowledge products need to be more effectively distributed, including in local languages, and materials that are made available need to be in forms that match the needs and capacity of their target audience. Simplified and demystified information products are required to dispel misconceptions about conservation planning and highlight the balance between top-down and bottom-up planning.

Misconceptions that planning is necessarily a "top down" process can generate reluctance amongst stakeholders to engage. Case studies such as those presented in Game et al..$^{18}$ and Weeks and Jupiter ${ }^{28}$ demonstrate that conservation planning tools and methods can be used as inputs for community-based decision making. Further examples that emphasise entire, participatory planning processes and place less emphasis on decision-support tools are required. NGO-led initiatives tend to be supported by expertise and funding rarely available to government agencies e.g. ${ }^{22}$. Case studies that demonstrate how conservation planning can be undertaken within the financial, technical, and resource constraints typical of government agencies within the Coral Triangle are needed. These are now emerging; an example is the recently approved and budgeted community-based conservation program in Timor-Leste, piloted under the USAID CTSP program ${ }^{29}$.

Finally, it will be necessary to demonstrate the benefits of planning, and costs of not planning, compared to counterfactual scenarios of unplanned expansion of MPAs or alternative management strategies ${ }^{19}$. For example, it can be demonstrated that objectives for biodiversity conservation can be achieved at a lower cost to resource-users under planned than unplanned scenarios ${ }^{19}$, and that opportunity costs to different users can be explicitly and transparently identified to minimise conflict $^{30}$.

\section{Integrating conservation planning with other planning processes}

Coastal areas and inshore waters are subject to many potentially competing planning processes, such as those for maritime transport, environmental protection, energy, fisheries, and tourism. Frameworks for marine spatial planning and integrated coastal zone management have been proposed to integrate the spatial aspects of sectoral policies in these diverse areas ${ }^{31}$. These frameworks aim to meet ecological, economic, and social objectives ${ }^{32}$, facilitate explicit trade-offs between competing uses, improve transparency in decision-making, and help to avoid unnecessary conflicts ${ }^{33,34}$. Yet coastal resource management in the Coral Triangle remains highly sectoral, with overlapping and incompatible jurisdictions, and unclear, and sometimes conflicting, mandates for different government agencies ${ }^{35,36}$. Aside from avoiding areas obviously incompatible with conservation (e.g. ports, shipping lanes), there are few examples of fully integrated spatial plans.

Spatial and non-spatial planning strategies relating to production and development sectors are likely to be better funded, more widely understood, and more strongly institutionalised within government (see section 4) than conservation planning. Consequently, to have influence, conservation plans must interface with and inject a conservation perspective into these planning processes. This integration has been referred to as mainstreaming conservation plans ${ }^{37,38}$. Failure of conservation planners to engage with the larger enterprise of marine spatial planning involves several risks: marginalisation of conservation objectives; unnecessary conflict between conservation plans and more influential, development initiatives; and adverse, avoidable impacts on local communities reliant on marine resources for subsistence or small cash economies.

Several advances are needed to better integrate conservation planning with the diverse aspects of marine spatial planning. Influence of conservation thinking on development planning requires anticipating commencement or reviews of development plans and policies, sectoral integration between agencies responsible for conservation and development planning, strong liaison of conservation scientists and NGOs with agencies responsible for development planning, and appropriately formatted information to provide inputs to processes 
for planning development ${ }^{37}$. Disparity between objectives can result in differences in structure and content between the outputs of conservation planning processes and those required for spatial planning more generally ${ }^{37}$. Integration can be facilitated if decisionsupport software tools developed to address the problem of prioritising areas for biodiversity conservation (e.g. Marxan, Zonation, C-Plan) are refocused to guide strategic expansion of development or extractive activities to have minimal impact on high-value sites for biodiversity ${ }^{39-42}$. An example would be to delineate shipping channels to minimise impacts on marine megafauna.

Some progress toward sectoral integration is evident in the Coral Triangle. In Indonesia, prior to laws relating to spatial planning and management of coastal areas and small islands passed in 2007, coastal resources were governed by a vast array of statutes and laws with dozens of implementing agencies ${ }^{35}$. Indonesia is now moving towards a more integrated approach ${ }^{43}$. However, local government agencies previously mandated to zone terrestrial and urban areas lack capacity in marine conservation planning ${ }^{44}$ (see "Building local capacity for conservation planning”).

Ultimately, effective integration of conservation objectives and priorities into marine spatial planning requires explicit analysis of tradeoffs: specifically, identifying the extent to which diverse objectives for conservation, development, and livelihoods are mutually exclusive, and providing a decision-making framework to resolve conflicts with a proper understanding of the implications of some objectives not being fully achieved ${ }^{45,46}$. The required methods are being devised, but have seldom been applied for real-world decisions, and remain inaccessible to emerging leaders in Coral Triangle countries.

\section{Building local capacity for conservation planning}

Since the CTI-CFF was conceived, building capacity has been a priority for all six Coral Triangle countries, which are presently under-resourced to support the $>1500$ existing MPAs, let alone achieve ambitious goals of protecting $20 \%$ of marine and coastal habitats by $2020^{12}$. Even countries with relatively well-developed capacity for marine conservation planning - Malaysia, Philippines, and Indonesia ${ }^{47}$ - have identified lack of in-country capacity as a key hurdle to achieving CTI-CFF goals ${ }^{36}$.

Although training on MPA management is available (from NGOs, government, and universities), lack of communication and coordination between training providers has led to delivery of non-standard modules, duplication, and omission of key competencies ${ }^{36}$. Furthermore, capacity building is often delivered as one-off training and, without follow-up assistance and mentoring, skills and knowledge acquired during training can be quickly lost. To undertake conservation planning, individuals, or at least planning teams, need to have a broad range of skills and knowledge that extend beyond those typically covered by existing training. Skills are needed in ecology, social science, the use of specialist software or GIS (geographic information systems), stakeholder engagement, communication, and negotiation, to name a few.

As a consequence of these limitations, managers of MPA networks depend heavily upon assisting organisations (e.g. NGOs, academe, development partners, or donors) for technical support with planning ${ }^{18,48}$. There are few organisations in the Coral Triangle with sufficient capacity to develop and implement effective conservation plans, and those that have the capacity are not sufficiently staffed or resourced to extend their support to all who request it. Broadening the base of technical experts will be crucial, especially in smaller countries such as the Solomon Islands, Timor-Leste, and Papua New Guinea, where existing experts are stretched to deliver support across the many problems requiring their attention ${ }^{49}$.

A common approach to develop capacity in the region is through peer-learning networks, such as the Philippine MPA Support Network, Papua New Guinea Centre for Locally Managed Areas, the regionally focused Coral Triangle Center in Bali, Indonesia, and the Locally Managed Marine Areas network, active in Solomon Islands and Indonesia. These learning networks facilitate cross-site visits and similar events that allow members to share experiences and lessons learned, and provide access to training modules or events. Although training often focuses on specific aspects of MPA management, learning networks could provide a venue through which information on conservation planning might also be disseminated.

A crucial solution to develop capacity in the long-term will be to create a new cohort of conservation planners from the region, through development of specific courses, qualifications, and competency standards that recognise marine conservation planning as a profession ${ }^{50}$. Targeting students in related disciplines with university short-courses and curricula ${ }^{51}$ that focus specifically on marine conservation planning would be a short-term step in this direction. The University of the Philippines' Marine Science Institute is currently developing a Masters program on Tropical Marine Ecosystem Management aimed at local government employees and MPA managers, which includes specialisations on MPAs and spatial planning. We envision that conservation planners will eventually be represented within the relevant national government agencies and local governments in the Coral Triangle region (see "Institutionalising conservation planning within governments").

Capacity might also be built through improved and sustained collaboration between scientists from developed nations and local research communities. For example, a Partnerships in International Research and Education (PIRE) project funded by the US National Science Foundation placed US graduate students and postdoctoral scholars in research institutions in Indonesia and Philippines for a year, providing improved laboratory infrastructure, research funding, and new educational opportunities for Filipino and Indonesian scientists and students ${ }^{27}$. USAID has also funded partnerships between US and Indonesian universities, fostering strong connections between Indonesian scientists and international collaborators ${ }^{27}$.

Institutionalising conservation planning within governments At present, conservation plans for regions within the Coral Triangle are frequently developed and implemented as projects led by NGOs or academic institutions with restricted time frames and limited budgets for engagement. Project-based conservation planning is undesirable for two reasons. First, supporting organisations have their own motivations for involvement in planning initiatives, which are manifest in the regions selected for planning effort: typically those with extraordinary biodiversity value or particular research interest $^{12,52}$. Thus, under the project model, conservation planning is spatially biased and will be undertaken only in few parts of the region. 
Second, conservation plans quickly become out-dated as ecological and socioeconomic conditions change. In the common case of protracted implementation, continuity of resources and expertise is required over extended time periods ${ }^{7}$. If plans are conceived and developed as finite projects, funds might not be secured for the ongoing implementation, adaptation, and revision required to keep them relevant, and personnel with capacity to interpret and update plans might be lost to lead organisations or redeployed to other roles. Institutionalising conservation planning within government will ensure that planning effort is invested much more widely, and is necessary if resources for protracted implementation and adaptation are to be maintained.

Institutionalizing conservation planning will present substantial challenges, but none appear to be intractable. Each of the six countries of the Coral Triangle has distinct governance arrangements with respect to spatial planning, biodiversity conservation, and management of coastal resources ${ }^{14}$. Approaches to institutionalise conservation planning will therefore need to be sensitive to these differences. Within-country differences in approach will also be necessary ${ }^{47}$. Governmental reform is seldom rapid, although the need to embed conservation planning in government at all levels is urgent. Still, the groundbreaking nature of the CTI-CFF itself, and the consequent progress toward multi-jurisdictional vertical (see "Integrating plans across governance levels") and horizontal (see "Planning across governance boundaries") cooperation, demonstrates that high-level reform for marine conservation is possible.

A practical first step towards institutionalizing conservation planning would be to review the current legislative and institutional environments, at different levels of government (including customary governance) in each country, to identify appropriate entry points at which authority, legitimacy, and willingness to undertake conservation planning overlap. For example, Indonesia has comprehensive legislation that requires district governments to prepare spatial plans. These same government units are responsible for implementing MPAs, and thus offer an entry point to integrate conservation planning perspectives (see section 1). In contrast, in Papua New Guinea, there is no formal legislation supporting declaration of MPAs or spatial planning. However, strong systems of traditional resource ownership and customary law ${ }^{53}$ provide an alternative route by which conservation plans can be developed and implemented by communities with customary tenure ${ }^{18}$, e.g. ${ }^{22}$. Here, conservation planning might better be institutionalised within customary, rather than formal, governance structures.

\section{Integrating plans across governance levels}

Levels of governance in the Coral Triangle range from international to national, sub-national (provinces, states), and local (e.g. municipalities, districts, communities). Decisions made at one level of governance influence the suite of actions available to, or mandated by, decision-makers at other levels ${ }^{54}$. Thus, spatial plans must be carefully integrated across spatial scales and levels of organisation $^{55,56}$ to avoid plans and policies that conflict, or are difficult to interpret or enforce.

Use of marine and coastal resources in the Coral Triangle is frequently subject to overlapping legislation and unclear jurisdictions, often with multiple implementing government agencies at different levels ${ }^{35,57}$. For example, in Indonesia, the enactment of a series of laws in 1999 shifted responsibility for spatial planning and coastal resource management from the national to the district level, leading to conflict with pre-existing laws and ambiguity regarding the roles and responsibilities of national, sub-national, and local government authorities $^{35}$. National, sub-national, and local governments' roles typically address different public needs and consequently can have different, sometimes conflicting, perspectives ${ }^{58}$. In many parts of the Coral Triangle, governance is further complicated by overlap of authority between formal and customary government systems: whilst customary tenure is recognised in national constitutions, traditional systems of natural resource management tend to be poorly integrated with national policies and legislation ${ }^{59}$.

Integration of conservation plans across governance levels should operate in two directions. First, region-wide initiatives such as the CTI-CFF need to be supported by actions at national, sub-national, and local levels by translating broad policy directives and planning principles into guidelines for identifying spatial priorities at progressively lower levels of governance. As seascape-scale planning initiatives become more common, there will be a need to ensure that these effectively inform local actions. This requires larger plans to be seen, not as static products, but as starting points for ongoing adaptation to changes in local circumstances, including unforeseen errors in seascape-scale data ${ }^{7}$. Similarly, national policies must be reflected in local plans. For example, in Malaysia, national regulations spatially demarcate a "commercial fishing zone" beyond three nautical miles from the coastline and a "traditional fishing zone" within that limit; these regulations provided a foundation for the process of zoning the Tun Mustapha Park, which subdivided the "traditional fishing zone"

Second, local marine management actions must be legally recognised and reinforced by higher levels of governance ${ }^{60}$. This is necessary both for local-level legislation, and customary governance. Otherwise, rules conceived and implemented locally might not be enforceable to outsiders who do not respect local customs and are beyond the reach of community-imposed punitive actions ${ }^{61,62}$. A further challenge is to anticipate and keep track of local actions not planned for at higher governance levels and the contribution that these make towards wider objectives. The Coral Triangle Marine Protected Area System (CTMPAS) framework, supported by the Coral Triangle Atlas, will play an important role in facilitating this ${ }^{63}$.

In some contexts, scale-bridging organisations and networks, such as the Solomon Islands' Locally Managed Marine Areas Network and Philippines' MPA Support Network, can play a critical role in facilitating interactions between levels of governance ${ }^{48,64}$. Other contexts might require legal reform, to ensure that plans consider existing laws and regulations at different scales ${ }^{65}$. Later revisions of Indonesia's decentralization framework, for example, sought to clarify jurisdictional roles by emphasizing relationships between national and district governments, rather than local autonomy ${ }^{35}$. Efforts to align policy across governance levels must be undertaken with care. In Papua New Guinea, efforts to strengthen coordination between national and provincial fisheries authorities had the unintended 
consequence of weakening links with local governments: provincial priorities became aligned with national interests (commercial fisheries) at the expense of local concerns ${ }^{58}$.

\section{Planning across governance boundaries}

The boundaries of natural resources rarely match those of the governance institutions responsible for managing them ${ }^{56,66}$. This is certainly true for marine resources in the Coral Triangle, where ecological connectivity processes can operate across spatial scales of tens to thousands of kilometres ${ }^{67,68}$, but where management is, for the most part, decentralised to local governments and communities ${ }^{69}$. Where the scale of ecological processes exceeds that of management jurisdictions, transboundary coordination is essential to avoid management efforts being insufficient to adequately protect the features and processes concerned. Furthermore, some benefits from management, such as enhanced recruitment arising from protection of spawning aggregations, might be realised beyond the boundaries of managing jurisdictions, undermining support for management ${ }^{70}$.

To achieve management outcomes across ecologically meaningful scales will require coordination of planning across governance boundaries $^{66,71}$, as well as arrangements for equitable sharing of the costs and benefits of management ${ }^{72}$. For example, if a fish spawningaggregation site is protected in one jurisdiction, complementary seasonal restrictions on catch of that species in neighbouring jurisdictions can provide increased ecological and fisheries benefits in all jurisdictions ${ }^{73}$. However, inequitable distribution of the costs and benefits of conservation among stakeholders or jurisdictions might result in social or political conflict, failure during implementation, or poor compliance with management regulations ${ }^{74,75}$. Plans that span multiple jurisdictions also need to incorporate multiple (sometimes divergent) objectives identified within different governance units ${ }^{76}$.

Transboundary planning might be most easily approached at local scales. This has been achieved to some extent in the Philippines, through the formation of local government alliances for coastal resource management ${ }^{48}$. Motivation for collaboration typically comes from recognition of a common resource base and shared threats, such as the intrusion of commercial fishing vessels into coastal waters ${ }^{77}$. Where such a shared vision is absent, neutral assisting organisations can act as brokers, helping to overcome social or political obstacles to coordination ${ }^{78,79}$. Alternatively, more innovative approaches to transboundary coordination, such as payments for transboundary ecosystem services ${ }^{80}$, might be required.

Planning across international boundaries is likely to present the greatest challenge. For example, achieving CTI-CFF goals on managing priority seascapes and ecosystem approaches to fisheries management will additionally require negotiating access to highvalue shared stocks (e.g. tuna), issues of national sovereignty, and financing ${ }^{79}$.

\section{Planning for multiple tools and objectives}

Marine conservation planning has, to date, focused largely on the design and implementation of 'no-take' MPAs and MPA networks, although approaches that consider multiple actions are emerging in the literature e.g. ${ }^{81}$. The establishment of a region-wide, comprehensive, ecologically representative, and well-managed CTMPAS is one of six strategic goals of the CTI-CFF ${ }^{4}$, and guidelines for the size and location of no-take MPAs in the Coral Triangle have recently been developed ${ }^{20}$. However, aside from the fact that few MPAs are presently well managed or adequately enforced ${ }^{14}$, there are two important limitations of no-take MPAs as tools for biodiversity conservation in this region. First, where local dependence on resources is high, and spatial or occupational mobility is limited (as in much of the Coral Triangle), no-take zones are necessarily small. The median size of no-take areas in the Philippines, for example, is just $0.12 \mathrm{~km}^{216}$. Furthermore, in some areas of the Coral Triangle, tradition or preference for alternative management strategies means that permanent no-take areas are rarely supported by stakeholders $^{70}$. Second, whilst no-take MPAs have proven benefits for biodiversity, fisheries and food security, they cannot manage many threats to marine and coastal ecosystems, such as land-based sources of nutrients and sediment or coral bleaching events related to climate change, and they offer only limited protection for migratory and wide-ranging species but see ${ }^{23,82}$.

Furthermore, if conservation planning is to be relevant to the CTICFF, it must address not only MPAs but also cross-sectoral integration of goals related to biodiversity, fisheries, and food security, and help to resolve inevitable trade-offs between these e.g. ${ }^{2}$. Part of this challenge is for conservation planning to move out of its comfort zone in designing networks of no-take MPAs to consider a wider range of coordinated management tools that can address all major threats at relevant scales ${ }^{83}$. The need for conservation planning to address a broad suite of actions is underlined by some simple facts: $90 \%$ of coral reefs in the Coral Triangle are under threat ${ }^{3}$, while $>80 \%$ of the region's coral reefs are likely to remain outside of the CTMPAS, and a large proportion of inshore reefs, whether inside or outside MPAs, are adversely affected by terrestrial runoff ${ }^{3}$.

The Coral Triangle has a long history of employing traditional and customary management practices other than no-take MPAs. Examples are temporary or periodically harvested fisheries closures variously known as sasi, tabu, or taboo, ${ }^{62,84}$. Conservation plans that employ familiar strategies such as these will likely be better supported locally ${ }^{70}$, and will fit within existing governance frameworks. Multiple-use zoning offers a more flexible approach to resource management that can help to resolve trade-offs between multiple objectives ${ }^{82}$. For example, in Indonesia's Nusa Penida MPA, multiple-use zoning was used to resolve conflict between marine tourism, seaweed farming, and fisheries activities, ensuring that the interests of all stakeholder groups were clearly represented in the plan ${ }^{12}$.

Planning for multiple tools, zones, or objectives is more complex than designing no-take MPA networks for biodiversity conservation. It requires more parameters to be estimated (with inevitable errors), increasing the need for plans to be adjusted when errors become apparent during implementation ${ }^{7}$, and requiring further iterations of planning and stakeholder consultations. For example, planning for multiple tools requires an understanding of the contribution of different management actions towards different objectives ${ }^{19}$.

Ideally, conservation planning would extend from inland watersheds to offshore waters, with integrated management of coasts and 
near-shore marine ecosystems ${ }^{85}$. Among the impediments to designing and implementing fully integrated land-sea planning is the need to work at multiple levels of governance (see "Integrating plans across governance levels") and across governance boundaries (see "Planning across governance boundaries"). Although planning methods are extending into this complexity of geography and governance ${ }^{86}$, practical applications of such integration in the Coral Triangle are rare.

\section{Understanding limitations of data}

Limitations of data are unavoidable in conservation planning ${ }^{87}$. These limitations apply not only to data on biodiversity, but also to data on costs, opportunities, threats, and other spatial variables that are increasingly being used to make spatial decisions ${ }^{7}$. This is especially true in the Coral Triangle, where data are generally sparser than in some other regions ${ }^{69,88,89}$. Whilst paucity of data should not necessarily be seen as an obstacle to initiating conservation planning processes, conservation decisions can be more effective in promoting the persistence of biodiversity and livelihoods if some important limitations of data are understood or avoided. We focus here on two aspects of mapped data: spatial resolution and surrogacy.

Spatial resolution refers to the size of the smallest homogeneous area that describes biodiversity, cost, opportunities, or threats. In general, the more extensive the coverage, the coarser is the spatial resolution of consistent data e.g..$^{90}$. This also means that fineresolution data tend to be available only in small parts of many planning regions, if at all. One implication is that priorities based on coarse-resolution data can be poorly aligned to those based on fine-resolution data available over smaller extents ${ }^{91}$. A related issue is that more extensive assessments tend to use larger planning units, sometimes even whole bioregions ${ }^{92}$, thereby blurring spatial variation between management units (e.g. traditional fishing grounds), which are generally very small in the Coral Triangle ${ }^{69}$, while also increasing estimates of overall conservation costs ${ }^{93,94}$. Discordance between the resolution at which priorities are identified and that required for decisions about on-ground management mean that extensive, coarse-resolution analyses have little to offer local managers $^{54}$. Importantly, there is no reason to assume that conservation priorities are spatially nested; very large planning units identified as priorities will not necessarily contain all the priority areas that would later be identified with smaller planning units?

Almost all data in conservation planning are surrogates, meaning that they approximate the variables of actual interest but for which spatial data are impossible to collect with available resources. Familiar examples are maps of ecosystems as surrogates for poorly mapped or still undescribed species ${ }^{8}$. For threats, distance to population centres might be a surrogate for exposure of marine waters to destructive fishing practices, even though actual threats vary with types of fishing gear used, attitudes of local fishing communities, dependence on types of marine resources, and links to markets ${ }^{66,95,96}$. With assessments that are more extensive and in regions with poorer data, conservation planning will rely on surrogates that are more remote from variables of primary importance, making priorities for conservation less reliable. In the Philippines, for example, coastal population density is strongly correlated with fishing pressure at the provincial scale but, at finer spatial resolutions, greater occupational diversity in more urbanised areas makes this a poor surrogate $^{97}$.

The most obvious solution to problems related to resolution and surrogacy of data is to collect more accurate information on variables of interest at the resolution of management units throughout the Coral Triangle. This is more easily said than done, of course, with about 800 coastal municipalities in the Philippines ${ }^{48}$, and many thousands of management units across the Coral Triangle. Nonetheless, whilst recognising that investment in data might compromise investment in conservation actions, better data will eventually lead to better planning. Demonstrations of the prospects for improved data in the Coral Triangle include the increasing quality and availability of remote-sensing imagery on coral reefs e.g. ${ }^{98}$, the potential to adjust collection of census information to improve socio-economic data for planning $^{99}$, and participatory mapping of resource use and features such as spawning aggregation sites, which has the added advantage of engaging local stakeholders in decisions about conservation.

In some cases, data and conservation assessments might simply have to be ignored because their use would be counterproductive. Data at very coarse resolution and based on unreliable surrogates will not only fail to resolve spatial variation relevant to applying actions, but can also pre-emptively divert attention from areas that would be identified as important, had better data been used. Similarly, very extensive conservation assessments that use large planning units can be counterproductive because two key (though generally implicit) assumptions are unreliable ${ }^{7}$ : uniformity (that priority is uniform within planning units); and nestedness (that high priorities at coarse resolution will contain all high-priority areas at fine resolution). These limitations mean that extensive prioritisations should be replaced with bottom-up assessments that build toward flexible regional designs.

Developing better measures of progress and effectiveness Conservation, whether for biodiversity or livelihoods, receives much attention globally through policy and legislation and large amounts of funding through diverse initiatives from governments, NGOs, and private donors. The objectives and performance of conservation initiatives, in the Coral Triangle and elsewhere, are measured mainly in terms of inputs (e.g. dollars invested), outputs (e.g. protected area extent), or, less commonly, outcomes (e.g. representation of marine ecosystems in protected areas). The widespread emphasis on outputs of marine conservation efforts is illustrated in the ongoing preoccupation with one of the internationally endorsed Aichi targets (Target 11, 10\% of marine and coastal areas under protection). Similarly, the CTI-CFF Regional Plan of Action "ultimate target" is to include $20 \%$ of each major marine and coastal habitat type in strictly no-take replenishment zones ${ }^{4}$.

The problem with these goals and measures is that outputs can be unrelated to progress for biodiversity conservation or livelihoods. For example, the extent of marine protected areas globally and in Australia reflects efforts made to establish them where they are most expedient politically and least required to protect biodiversity ${ }^{100}$. In terms of livelihoods, there is little evidence that the extent of protected areas is related to benefits to people ${ }^{101}$. Even outcomes can be poor measures of actual progress. For example, increases in 
representativeness, the number of ecosystems covered by protected areas, can mask simultaneous increases in the bias of protection away from those ecosystems most in need of protection ${ }^{102,103}$.

Measuring conservation progress in terms of inputs, outputs, and outcomes results in means (establishing protected areas) being confused with ends (making a positive difference for biodiversity or livelihoods). Fundamentally, marine protected areas and related management actions are intended to make a positive difference, yet this difference is almost never measured.

The emerging field of conservation impact evaluation ${ }^{104}$ promises to enable funders and policy-makers to extend measures of progress and effectiveness to assess directly how much difference existing conservation actions make to biodiversity and livelihoods, or how much difference future actions could make. Impact evaluation measures the effects of an intervention by comparing what happened with the intervention compared with what would have happened without the intervention (i.e. the counterfactual; ${ }^{105}$ ). It is important to note that impact evaluation of conservation initiatives is very distinct from environmental impact assessment of development projects.

Over and above measures of inputs, outputs, and outcomes, impact evaluation offers two critical improvements. The first is attribution - ensuring that the observed changes flow from the intervention being assessed, not from unrelated contextual changes ${ }^{106}$. It is important, for example, to understand whether livelihoods improve in response to a conservation initiative, as distinct from increased living standards across a region related to, say, macroeconomic changes. The second improvement provided by impact over other measures is the distinction between means and ends ${ }^{6}$. If the ultimate goal of a program is to reduce the loss of biodiversity, then impact is the amount of loss avoided, relative to the amount had the program had not been implemented. Approaches to measuring the impact of protected areas retrospectively, to provide lessons for the future, are now well developed ${ }^{107}$. Approaches to predicting where future protected areas could have greatest positive impact are also available ${ }^{108}$.

The existing work on impact evaluation of protected areas, although mostly focused on terrestrial ecosystems, can now be adapted and applied to marine conservation in the Coral Triangle. Following the lead of the health and energy sectors ${ }^{106}$, impact evaluation can also be extended to diverse on-ground interventions, such as partial fisheries closures, and strategic interventions including legislation, policy, and education. For these changes to happen, one requirement is applied research to adapt and extend existing methods for impact evaluation to the Coral Triangle, accounting for available data, capacity and the diversity of social and governance contexts. The other need is for impact evaluation theory and methods to be made more accessible to policy makers and practitioners in the Coral Triangle (see "Making conservation planning accessible"). A first step towards this is to ensure that established monitoring and evaluation programs produce data that can be used to assess impacts.

\section{Making a long-term commitment}

The long-term commitment required for effective conservation planning is generally under-appreciated ${ }^{7,109}$. Temporal-scale mismatches arise where short funding or electoral cycles conflict with long-term planning needs ${ }^{56}$, and there has been a tendency towards funding models that value short-term project outputs, such as the development of conservation prioritisations or plans on paper, over long-term, effectively implemented outcomes (see "Developing better measures of progress and effectiveness"). This is likely driven in part by the ease of demonstrating fulfilment of project goals linked to outputs, as opposed to less tangible outcomes, such as increased capacity of communities to undertake adaptive management. Another crucial factor is the time taken for the conservation impact of investments to become manifest and the general lack of methods for measuring impact ${ }^{6}$. Focusing on short-term outputs fails to recognise that spatial prioritisation is merely the first, and arguably the easiest, phase of conservation planning, and must be followed by protracted processes of application ${ }^{7}$, monitoring, and ongoing adaptive management and planning. Failure to conceive, and adequately fund, conservation planning as a complete planning - implementation package is a major reason why plans have failed to find traction in many parts of the world ${ }^{109}$. Approaches that acknowledge the need for application but allow insufficient time or funds might attempt to expedite implementation but, in doing so, risk losing the support of stakeholders, leading to poor compliance and failure.

Making a long-term commitment to conservation planning requires a single organisation with responsibility for steering planning outputs towards sustained outcomes. This will be realised through a shift from project-based conservation planning, towards planning processes institutionalised within government or NGOs (see "Institutionalising conservation planning within governments"). This change in approach also requires a move away from project-oriented funding models by governments and donors towards institutionalised allocations for conservation planning that are increasingly embedded within government structures.

Whilst short-term political cycles are unlikely to change, opportunities might exist to safeguard conservation plans and actions against changes in political leadership or environmental orientation. At local governance levels, leadership and legislative processes tend to move more quickly than at higher levels, facilitating rapid implementation, but also allowing laws to be quickly revoked. One way to buffer against potential setbacks at the local level is to reinforce conservation plans through legislation at higher levels of government (see "Integrating plans across governance levels"). This strategy was adopted for the Sumilon Marine Reserve in the Philippines after a newly-elected local mayor with links to commercial fishing operations actively sought to degazette the MPA ${ }^{110}$. Another example is the new Solomon Islands National Protected Areas Act, which establishes a legal process for national recognition of subnationally established protected areas. There is a risk that formalising local conservation plans under national legislation can negate other benefits of localised governance, such as ownership and adaptive capacity e.g. ${ }^{11}$, but this risk can be offset by transparency and participative processes.

Until long-term commitments to planning are accepted and adequately supported, planning teams dependent upon short-term funding cycles must learn to work more effectively within these constraints. For example, planning teams could communicate long-term objectives to donors and package constituent parts of the planning-implementation process as a sequence of stand-alone projects that appeal to donors, rather than focusing only on outputs or promising rapid progress to outcomes. Likewise, donors must 
understand that quick fixes and simplistic measures of success (see "Making a long-term commitment") can be counterproductive; conservation success needs long-term funding, or more modest shortterm objectives as part of a longer sequence from plans to actions. Two critical needs are longer-term visions and realistic expectations of outcomes. These expectations might include capacity building, consolidating the effectiveness of existing conservation actions (not just establishing new ones), and other such activities that have less concrete or prestigious outputs, yet contribute towards meaningful outcomes.

Much was made of the huge scale of investment by international donors and NGOs at the inception of the CTI-CFF (http://www. usaid.gov/global-waters/november-2010/coral-triangle). Yet achieving the Initiative's goals will take decades, and it is likely that the resources required to do this have been seriously underestimated. It was difficult for the architects of such an ambitious initiative to appreciate the full implications of its geographic and political scale, the complexity of resource-management challenges to be resolved, and the required building of capacity to ensure local ownership of plans and sustainability of management actions into the future. It was even more difficult for governments and private donors to commit funds for what was always to be a decades-long enterprise.

Only time will tell whether the CTI-CFF itself will secure the long-term commitment required at all scales and levels of governance to achieve lasting outcomes. There are the seeds of a single organisation to provide oversight and coordination in the CTI-CFF Regional Secretariat, currently hosted by Indonesia. Still in early stages, the Regional Secretariat has the potential to guide a shift from project-based conservation planning, towards planning processes institutionalised within the six CTI-CFF governments (see "Institutionalising conservation planning within governments"). This will require leadership and organisations with conservation planning capacity at all scales and levels of governance.

\section{Conclusions}

The challenges to successful implementation of conservation planning in the Coral Triangle are primarily related to issues of governance, capacity, knowledge flow, and communication. Although understanding of biodiversity patterns, processes, threats, and how to manage them continues to develop, current scientific knowledge is generally sufficient to develop effective conservation plans. Addressing the challenges discussed above will open the way for more sophisticated planning approaches, such as explicit incorporation of ecological connectivity.

Getting our ten things right for marine conservation planning will be difficult, and might seem overwhelming. But the first five years of the CTI-CFF have seen progress on multiple fronts that, for many observers, would have been unimaginable beforehand. In the right-hand column of Table 1, we highlight some immediate ways forward in resolving the challenges that we have reviewed. These ways forward require action, from researchers, governments, donors, and practitioners.

Present shortcomings in the application of marine conservation planning, such as the incompatible spatial scale of many conservation prioritisations, have contributed to misconceptions about the suitability of conservation planning generally and, specifically, its appropriateness in the Coral Triangle. Resolving these shortcomings conceptually, and demonstrably through contextually-relevant case studies, will help to overcome barriers to adoption of conservation planning approaches.

Nevertheless, whilst case-study prototypes and "best-practice" guidelines can be useful to encourage uptake of a new approach, planners working in the Coral Triangle must have the flexibility to develop strategies that are responsive to local needs and conditions, without needing to comply with standard approaches ${ }^{112}$. Governance, capacity, planning cultures, and traditions of management of natural resources vary widely within and among the Coral Triangle countries, so there will not be a "one size fits all" approach to conservation planning. Likewise, each of the challenges discussed above will play out differently, and assume different relative importance and urgency, in different geographies and contexts.

Perhaps the most important thing to get right, if conservation planning is to have real impact in the Coral Triangle, is a conceptual shift from conservation planning undertaken as a project, to planning undertaken as a process. Process-oriented planning commits agencies and stakeholders to long-term engagement, which is essential to transform conservation plans on paper into successful outcomes in the long-term. Increasingly, Coral Triangle governments are adopting leadership roles at different levels and scales, as reflected in increasing national and sub-national budget allocations for conservation planning. These leaders need direct support to ensure that emerging approaches and tools become institutionalised. Finally, conservation planning should not be considered as a new paradigm for the Coral Triangle, adding to the workload of conservation practitioners and government agencies charged with natural resource management. Instead, conservation planning can be correctly seen as a way of integrating the multiple goals of the CTI-CFF and diverse additional goals to which governments are already committed.

\section{Author contributions}

RW and RLP conceived the study. All authors participated in discussions to identify and explore the ten topics. RW, RLP and JRW prepared the first draft. VH, MK, RA, and RAA revised subsequent drafts of the manuscript and all authors have agreed to the final content.

\section{Competing interests}

No competing interests were disclosed.

\section{Grant information}

The focus group from which this manuscript originated was made possible by funding support from the Australian Research Council provided to RLP. RW, RLP and VH acknowledge the Australian Research Council for funding support. The participation of MK and RA was made possible by the generous support of the American people through the United States Agency for International Development (USAID). The contents are the responsibility of the authors and do not necessarily reflect the views of USAID or the United States Government. 
1. Allen GR: Conservation hotspots of biodiversity and endemism for Indo-Pacific coral reef fishes. Aquat Conserv. 2008; 18(5): 541-556.

Publisher Full Text

2. Foale $S$, Adhuri $D$, Aliño $P$, et al.: Food security and the Coral Triangle Initiative. Mar Policy. 2013; 38: 174-183.

Publisher Full Text

3. Burke L, Reytar K, Spalding M, et al.: Reefs at Risk Revisited in the Coral Triangle. World Resources Institute, Washington, DC. 2012. Reference Source

4. CTI-CFF: Coral Triangle Initiative on Coral Reefs, Fisheries and Food Security Regional Plan of Action. Jakarta, Indonesia. 2009. Reference Source

5. Weeks $\mathrm{R}$, et al.: Establishing a region-wide system of marine protected areas in the Coral Triangle. Coast Manage. 2014; 42(2): 81-86. Reference Source

6. Bottrill MC, Pressey RL: The effectiveness and evaluation of conservation planning. Conserv Lett. 2012; 5(6): 407-420.

Publisher Full Tex

7. Pressey RL, Mills M, Weeks R, et al.: The plan of the day: Managing the dynami transition from regional conservation designs to local conservation actions. Biol Conserv. 2013; 166: 155-169.

Publisher Full Text

8. Margules CR, Pressey RL: Systematic conservation planning. Nature. 2000 405(6783): 243-253. PubMed Abstract | Publisher Full Text

9. Gaines SD, White C, Carr MH, et al:: Designing marine reserve networks for both conservation and fisheries management. Proc Natl Acad Sci U S A. 2010; 107(43): 18286-18293.

PubMed Abstract | Publisher Full Text | Free Full Text

10. Poiani KA, Baumgartner JV, Buttrick SC, et al: A scale-independent, site conservation planning framework in The Nature Conservancy. Landscape Urban Plan 1998: 43(1-3): 143-156. Publisher Full Text

11. Holness SD, Biggs HC: Systematic conservation planning and adaptive management Koedoe 2011; 53(2): 34-42. Publisher Full Text

12. Weeks R, Aliño PM, Atkinson S, et al:: Developing marine protected area networks in the Coral Triangle: good practices for expanding the Coral Triangle marine protected area system. Coast Manage. 2014; 42(2): 183-205. Publisher Full Text

13. Halpern BS, Klein CJ, Brown CJ, et al.: Achieving the triple bottom line in the face of inherent trade-offs among social equity, economic return, and conservation. Proc Natl Acad Sci U S A. 2013; 110(15): 6229-6234. PubMed Abstract | Publisher Full Text | Free Full Text

14. White AT, Aliño PM, Cros A, et al:: Marine protected areas in the Coral Triangle: progress, issues, and options. Coast Manage. 2014; 42(2): 87-106. Publisher Full Text

15. Cumming GS, Cumming DHM, Redman CL, et al:: Scale mismatches in socialecological systems: causes, consequences, and solutions. Ecol Soc. 2006; 11(1): 14 .

Reference Source

16. Weeks R, Russ GR, Alcala AC, et al:: Effectiveness of marine protected areas in the Philippines for biodiversity conservation. Conserv Biol. 2010; 24(2): 531-540.

PubMed Abstract | Publisher Full Text

17. Green SJ, White AT, Christie P, et al.: Emerging marine protected area networks in the coral triangle: Lessons and way forward. Conserv Soc. 2011; 9(3): 173-188.

Publisher Full Text

18. Game ET, Lipsett-Moore G, Hamilton R, et al:: Informed opportunism for conservation planning in the Solomon Islands. Conserv Lett. 2011; 4(1): 38-46. Publisher Full Text

19. Mills M, Adams VM, Pressey RL, et al: Where do national and local conservation actions meet? Simulating the expansion of ad hoc and systematic approaches to conservation into the future in Fiji. Conserv Lett. 2012; 5(5): 387-398. Publisher Full Text

20. Fernandes L, Green A, Tanzer J, et al.: Biophysical principles for designing resilient networks of marine protected areas to integrate fisheries, biodiversity and climate change objectives in the Coral Triangle. Report prepared by The Nature Conservancy for the Coral Triangle Support Partnership. 2012. Reference Source

21. Grantham HS, Agostini VN, Wilson $J$, et al: A comparison of zoning analyses to inform the planning of a marine protected area network in Raja Ampat, Indonesia. Mar Policy. 2012; 38: 184-194. Publisher Full Text

22. Green A, Smith SE, Lipsett-Moore G, et al.: Designing a resilient network of marine protected areas for Kimbe Bay Papua New Guinea. Oryx. 2009; 43(4): 488-498.

Publisher Full Text
23. Wilson J, Darmawan A, Subijanto J, et al.: Scientific Design of a Resilient Network of Marine Protected Areas. Lessa Sunda Ecoregion, Coral Triangle, The Nature Conservancy Asia Pacific Marine Prorgam. 2011. Reference Source

24. Christie P, White AT: Best practices for improved governance of coral reef marine protected areas. Coral Reefs. 2007; 26(4): 1047-1056.

Publisher Full Text

25. Clifton J: Science, funding and participation: key issues for marine protected area networks and the Coral Triangle Initiative. Envir Conserv. 2009; 36(2): $91-96$ Publisher Full Text

26. Christie P, Pollnac R, Stevenson T, et al.: Lessons from the US Coral Triangle Initiative Support Program: Final Report. US Coral Triangle Partnership. 2014. Reference Source

27. Barber $\mathrm{PH}$, Ablan-Lagman MCA, Berlinck RGS, et al:: Advancing biodiversity research in developing countries: the need for changing paradigms. B Mar Sci. 2014; 90(1): 187-210. Publisher Full Text

28. Weeks R, Jupiter SD: Adaptive comanagement of a marine protected area network in Fiji. Conserv Biol. 2013; 27(6): 1234-1244. PubMed Abstract | Publisher Full Text

29. Pereira CC, Pinto R, Mohan C, et al.: Guidelines for Establishing CoManagement of Natural Resources in Timor-Leste, Conservation Internationa for the Timor-Leste National Coordinating Committee. 2013. Reference Source

30. Klein CJ, Tulloch VJ, Halpern BS, et al.: Tradeoffs in marine reserve design: habitat condition, representation, and socioeconomic costs. Conserv Lett. 2013; 6(5): 324-332. Publisher Full Text

31. Chua TE: The Dynamics of Integrated Coastal Management: Practica Applications in the Sustainable Coastal Development in East Asia, Partnerships in Environmental Management for the Seas of East Asia (PEMSEA). 2006. Reference Source

32. Zacharoula $\mathrm{K}$, Frank $\mathrm{M}$, Marijn $\mathrm{R}$, et al.: The integration of nature conservation into the marine spatial planning process. Mar Policy. 2013; 38: 133-139. Publisher Full Text

33. White C, Halpern BS, Kappel CV, et al.: Ecosystem service tradeoff analysis reveals the value of marine spatial planning for multiple ocean uses. Proc Natl Acad Sci U S A. 2012; 109(12): 4696-4701.

Publisher Full Text

34. Foley MM, Halpern BS, Micheli F, et al.: Guiding ecological principles for marine spatial planning. Mar Policy. 2010; 34(5): 955-966. Publisher Full Text

35. Patlis JM: The role of law and legal institutions in determining the sustainability of integrated coastal management projects in Indonesia. Ocean \& Coast Manage. 2005; 48(3-6): 450-467. Publisher Full Text

36. Asian Development Bank: The Regional State of the Coral Triangle Report. Asian Development Bank, Manila. 2014 Reference Source

37. Pierce SM, Cowling RM, Knight AT, et al.: Systematic conservation planning products for land-use planning: Interpretation for implementation. Bio/ Conserv. 2005; 125(4): 441-458. Publisher Full Text

38. Cowling RM, Egoh B, Knight AT, et al: An operational model for mainstreaming ecosystem services for implementation. Proc Natl Acad Sci U S A. 2008 105(28): 9483-9488.

PubMed Abstract | Publisher Full Text | Free Full Text

39. Gordon A, Simondson D, White $\mathrm{M}$, et al.: Integrating conservation planning and landuse planning in urban landscapes. Landscape Urban Plan. 2009; 91(4): 183-194.

Publisher Full Text

40. Kiesecker JM, Copeland H, Pocewicz A, et al.: Development by design: blending landscape-level planning with the mitigation hierarchy. Front Ecol Environ. 2010; 8(5): 261-266. Publisher Full Text

41. Ban NC, Vincent ACJ: Beyond marine reserves: exploring the approach of selecting areas where fishing is permitted, rather than prohibited. PLoS One. 2009; 4(7): e6258. PubMed Abstract | Publisher Full Text | Free Full Text

42. Kareksela S, Moilanen A, Tuominen S, et al:: Use of inverse spatial conservation prioritization to avoid biological diversity loss outside protected areas. Conserv Biol. 2013; 27(6): 1294-1303. PubMed Abstract | Publisher Full Text

43. Mangubhai S, Erdmann MV, Wilson JR, et al.: Papuan Bird's Head Seascape: emerging threats and challenges in the global center of marine biodiversity. Mar Pollut Bull. 2012; 64(11): 2279-2295. PubMed Abstract | Publisher Full Text 
44. Nurhidayah L: Integrated coastal zone management in Indonesia: The implementation and its challenges. 2010. Publisher Full Text

45. Polasky S: Why conservation planning needs socioeconomic data. Proc Natl Acad Sci U S A. 2008; 105(18): 6505-6506. PubMed Abstract | Publisher Full Text | Free Full Text

46. Adams VM, Álvarez-Romero JG, Carwardine J, et al.: Planning across freshwater and terrestrial realms: cobenefits and tradeoffs between conservation actions. Conserv Lett. 2014 Publisher Full Text

47. Cabral R, Cruz-Trinidad A, Geronimo R, et al:: Opportunities and Challenges in the Coral Triangle. Environ Sci Technol. 2012; 46(15): 7930-7931. PubMed Abstract | Publisher Full Text

48. Horigue V, Aliño PM, White AT, et al:: Marine protected area networks in the Philippines: Trends and challenges for establishment and governance. Ocean Coast Manage. 2012; 64: 15-26.

Publisher Full Text

49. Sulu RJ, et al:: State of the Coral Reefs of Solomon Islands, Solomon Islands National Coordinating Committee, Honiara. 2012.

50. Sayer J, Sunderland T, Ghazoul J, et al.: Ten principles for a landscape approach to reconciling agriculture, conservation, and other competing land uses. Proc Natl Acad Sci U S A. 2013; 110(21): 8349-8356. Publisher Full Text

51. Bonine K, Reid J, Dalzen R, et al:: Training and education for tropical conservation. Conserv Biol. 2003; 17(5): 1209-1218. Publisher Full Text

52. Carpenter KE, Springer VG: The center of the center of marine shore fish biodiversity: the Philippine Islands. Environ Biol Fish. 2005; 72(4): 467-480. Publisher Full Text

53. Cinner JE, Basurto X, Fidelman P, et al:: Institutional designs of customary fisheries management arrangements in Indonesia, Papua New Guinea, and Mexico. Mar Policy. 2012; 36(1): 278-285. Publisher Full Text

54. Cash DW, Moser SC: Linking global and local scales: designing dynamic assessment and management processes. Global Environ Chang. 2000; 10(2): 109-120.

Publisher Full Text

55. Adger WN, Brown K, Tompkins EL, et al.: The political economy of cross-scale networks in resource co-management. Ecol Soc. 2005; 10(2): 9.

Reference Source

56. Cash DW, Adger WN, Berkes F, et al.: Scale and cross-scale dynamics: governance and information in a multilevel world. Ecol Soc. 2006; 11(2): 8 Reference Source

57. National CTI Coordinating Committee of Malaysia State of the Coral Triangle Report: Malaysia. 2012

58. Benson CS: Shifting accountabilities? Understanding the connections between national and provincial fisheries in Papua New Guinea. Mar Policy. 2012; 36(4): 859-866.

Publisher Full Text

59. Fidelman $P$, Evansa L, Fabinyia M, et al:: Governing large-scale marine commons: Contextual challenges in the Coral Triangle. Mar Policy. 2012; 36(1): 42-53.

Publisher Full Text

60. Ostrom E: Governing the commons: The evolution of institutions for collective action. Cambridge University Press. 1990

Reference Source

61. Clarke P, Jupiter SD: Law custom and community-based natural resource management in Kubulau District (Fiji). Envir Conserv. 2010; 37(1): 98-106. Publisher Full Text

62. McLeod E, Szuster B, Salm R, et al:: Sasi and marine conservation in Raja Ampat, Indonesia. Coast Manage. 2009; 37(6): 656-676. Publisher Full Text

63. Walton A, White AT, Tighe $S$, et al: Establishing a functional region-wide Coral Triangle marine protected area system. Coast Manage. 2014; 42(2): 107-127. Publisher Full Text

64. Cohen PJ, Evans LS, Mills M: Social networks supporting governance of coastal ecosystems in Solomon Islands. Conserv Lett. 2012; 5(5): 376-386. Publisher Full Text

65. McLeod E, Salm R, Green A, et al.: Designing marine protected area networks to address the impacts of climate change. Front Ecol Environ. 2009; 7(7): 362-370. Publisher Full Text

66. Berkes F: From community-based resource management to complex systems: the scale issue and marine commons. Ecol Soc. 2006; 11(1): 45 Reference Source

67. Treml EA, Halpin PN: Marine population connectivity identifies ecological neighbors for conservation planning in the Coral Triangle. Conserv Lett. 2012; 5(6): 441-449

Publisher Full Text

68. Kool JT, Paris CB, Barber PH, et al.: Connectivity and the development of population genetic structure in Indo-West Pacific coral reef communities. Global Ecol Biogeogr. 2011; 20(5): 695-706.

Publisher Full Text

69. Mills M, Pressey RL, Weeks R, et al:: A mismatch of scales: challenges in planning for implementation of marine protected areas in the Coral Triangle. Conserv Lett. 2010; 3(5): 291-303.

Publisher Full Text

70. Foale S, Manele B: Social and political barriers to the use of marine protected areas for conservation and fishery management in Melanesia. Asia Pac Viewp. 2004; 45(3): 373-386.

Publisher Full Text

71. Millennium Ecosystem Assessment: Ecosystems and human well-being: a framework for assessment. Island Press, Washington, DC. 2003. Reference Source

72. Weeks R, Russ GR, Bucol AA, et al.: Incorporating local tenure in the systematic design of marine protected area networks. Conserv Lett. 2010; 3(6): 445-453. Publisher Full Text

73. Almany GR, Hamilton RJ, Bode M, et al.: Dispersal of grouper larvae drives local resource sharing in a coral reef fishery. Curr Biol. 2013; 23(7): 626-630. PubMed Abstract | Publisher Full Text

74. Cinner JE, Aswani S: Integrating customary management into marine conservation. Biol Conserv. 2007; 140(3-4): 201-216. Publisher Full Text

75. Klein CJ, Steinback C, Watts M, et al:: Spatial marine zoning for fisheries and conservation. Front Ecol Environ. 2010; 8: 349-353. Publisher Full Text

76. Horigue $\mathrm{V}$, et al.: Influence of governance context on the management performance of marine protected area networks in the Philippines. Coast Manage (In Press)

77. Lowry GK, Whiteb AT, Christiec $P$, et al:: Scaling up to networks of marine protected areas in the Philippines: biophysical, legal, institutional, and social considerations. Coast Manage. 2009; 37(3-4): 274-290. Publisher Full Text

78. Espectato LN, Serofia GD, Subade RF, et al:: Emerging fisheries co-management arrangement in Panay Gulf, Southern Iloilo, Philippines. Ocean Coast Manage. 2012; 55: 27-35.

Reference Source

79. Mackelworth P: Peace parks and transboundary initiatives: implications for marine conservation and spatial planning. Conserv Lett. 2012; 5(2): 90-98. Publisher Full Text

80. López-Hoffman L, Varady RG, Flessa KW, et al:: Ecosystem services across borders: a framework for transboundary conservation policy. Front Ecol Environ. 2010; 8(2): 84-91.

Publisher Full Text

81. Carwardine J, O'Connor T, Legge S, et al:: Prioritizing threat management for biodiversity conservation. Conserv Lett. 2012; 5(3): 196-204. Publisher Full Text

82. Agardy T, di Sciarab GN, Christie P: Mind the gap: Addressing the shortcomings of marine protected areas through large scale marine spatial planning. Mar Policy. 2011; 35(2): 226-232. Publisher Full Text

83. Hughes TP, Graham NA, Jackson JB, et al:: Rising to the challenge of sustaining coral reef resilience. Trends Ecol Evol. 2010; 25(11): 633-642. PubMed Abstract | Publisher Full Text

84. Cohen PJ, Foale SJ: Sustaining small-scale fisheries with periodically harvested marine reserves. Mar Policy. 2013; 37: 278-287. Publisher Full Text

85. Álvarez-Romero JG, Pressey RL, Ban NC, et al.: Integrated Land-Sea Conservation Planning: The Missing Links. Annu Rev Ecol Evol Syst. 2011; 42: 381-409.

Publisher Full Text

86. Klein CJ, Jupiter SD, Watts M, et al:: Evaluating the influence of candidate terrestrial protected areas on coral reef condition in Fiji. Mar Policy. 2014; 44: 360-365.

Publisher Full Text

87. Pressey RL: Conservation planning and biodiversity: assembling the best data for the job. Conserv Biol. 2004; 18(6): 1677-1681.

Publisher Full Text

88. Johannes RE: The case for data-less marine resource management: examples from tropical nearshore finfisheries. Trends Ecol. Evol. 1998; 13(6): 243-246. Publisher Full Text

89. Christie P, Pollnac RB, Oracion EG, et al.: Back to basics: An empirical study demonstrating the importance of local-level dynamics for the success of tropical marine ecosystem-based management. Coast Manage. 2009; 37(3-4): 349-373.

Publisher Full Text

90. Donald PF, Fuller RJ: Ornithological atlas data: a review of uses and limitations. Bird Study. 1998; 45(2): 129-145.

Publisher Full Text 
91. Rouget M: Measuring conservation value at fine and broad scales: implications for a diverse and fragmented region, the Agulhas Plain. Biol Conserv. 2003; 112(1-2): 217-232. Publisher Full Text

92. Klein CJ, Ban NC, Halpern BS, et al.: Prioritizing land and sea conservation investments to protect coral reefs. PLoS One. 2010; 5(8): e12431. PubMed Abstract | Publisher Full Text | Free Full Text

93. Pressey RL, Logan VS: Size of selection units for future reserves and its influence on actual vs targeted representation of features: a case study in western New South Wales. Biol Conserv. 1998; 85(3): 305-319. Publisher Full Text

94. Adams VM, Segan DB, Pressey RL: How much does it cost to expand a protected area system? Some critical determining factors and ranges of costs for Queensland. PLoS One. 2011; 6(9): e25447. PubMed Abstract | Publisher Full Text | Free Full Text

95. McClanahan TR, Marnane MJ, Cinner JE, et al: : A comparison of marin protected areas and alternative approaches to coral-reef management. Curr Biol. 2006; 16(14): 1408-1413. PubMed Abstract | Publisher Full Text

96. Brewer TD, Cinner JE, Green A, et al:: Thresholds and multiple scale interaction of environment, resource use and market proximity on reef fishery resources in the Solomon Islands. Biol Conserv. 2009; 142(8): 1797-1807. Publisher Full Text

97. Weeks R, Russ GR, Bucol AA, et al:: Shortcuts for marine conservation planning: The effectiveness of socioeconomic data surrogates. Biol Conserv. 2010; 143(5): 1236-1244.

Publisher Full Text

98. Andrefouet S, Muller-Karger FE, Robinson JA, et al:: Global assessment of modern coral reef extent and diversity for regional science and management applications: a view from space. Proceedings of 10th International Coral Reef Symposium, Okinawa, Japan. June 28-July 2, 2004, 2006; 1732-1745. Reference Source

99. Brewer TD, Cinner JE, Green A, et al:: Effects of human population density and proximity to markets on coral reef fishes vulnerable to extinction by fishing. Conserv Biol. 2013; 27(3): 443-452. PubMed Abstract | Publisher Full Text

100. Devillers R, Pressey RL, Grech A, et al:: Reinventing residual reserves in the sea: are we favouring ease of establishment over need for protection? Aquat Conserv. 2014. Publisher Full Text

101. Mascia MB, Claus CA, Naidoo R: Impacts of marine protected areas on fishing communities. Conserv Biol. 2010; 24(5): 1424-1429. PubMed Abstract | Publisher Full Text

102. Pressey RL, Taffs KH: Sampling of land types by protected areas: three measures of effectiveness applied to western New South Wales. Biol Conserv. 2001; 101(1): 105-117. Publisher Full Text

103. Pressey RL, Whish GL, Barrett TW, et al:: Effectiveness of protected areas in north-eastern New South Wales: recent trends in six measures. Biol Conserv. 2002; 106(1): 57-69. Publisher Full Text

104. Ferraro PJ, Pattanayak SK: Money for nothing? A call for empirical evaluation of biodiversity conservation investments. PLoS Biol. 2006; 4(4): e105. PubMed Abstract | Publisher Full Text | Free Full Text

105. Gertler PJ, Martinez S, Premand P, et al.: Impact Evaluation in Practice, World Bank Publications. 2011. Reference Source

106. Ferraro PJ: Counterfactual thinking and impact evaluation in environmental policy. New Directions for Evaluation. 2009; 2009(122): 75-84. Publisher Full Text

107. Nolte C, Agrawal A, Silvius KM, et al:: Governance regime and location influence avoided deforestation success of protected areas in the Brazilian Amazon. Proc Natl Acad Sci U S A. 2013; 110(13): 4956-4961. PubMed Abstract | Publisher Full Text | Free Full Text

108. Withey JC, Lawler JJ, Polasky S, et al:: Maximising return on conservation investment in the conterminous USA. Ecol Lett. 2012; 15(11): 1249-1256. PubMed Abstract | Publisher Full Text

109. Knight AT, Cowling RM, Rouget M, et al:: Knowing but not doing: selecting priority conservation areas and the research-implementation gap. Conserv Biol. 2008; 22(3): 610-617. PubMed Abstract | Publisher Full Text

110. Russ GR, Alcala AC: Management histories of Sumilon and Apo Marine Reserves, Philippines, and their influence on national marine resource policy. Coral Reefs. 1999; 18(4): 307-319. Publisher Full Text

111. Hind EJ, Hiponiab MC, Gray TS: From community-based to centralised national management-A wrong turning for the governance of the marine protected area in Apo Island, Philippines? Mar Policy. 2010; 34(1): 54-62. Publisher Full Text

112. Game ET, Meijaard E, Sheil D, et al.: Conservation in a wicked complex world; challenges and solutions. Conserv Lett. 2013.

Publisher Full Text 


\section{Open Peer Review}

\section{Current Peer Review Status:}

\section{Version 1}

Reviewer Report 15 May 2014

https://doi.org/10.5256/f1000research.4162.r4516

(C) 2014 Fidelman P. This is an open access peer review report distributed under the terms of the Creative Commons Attribution License, which permits unrestricted use, distribution, and reproduction in any medium, provided the original work is properly cited.

\section{Pedro Fidelman}

Sustainability Research Centre, University of the Sunshine Coast, Sunshine Coast, Qld, Australia

The paper, based mostly on expert opinion, identifies and discusses challenges to marine conservation planning in the Coral Triangle - a region where, despite pressing conservation issues, conservation planning has had relatively limited influence. The paper provides insights to inform management actions in the Coral Triangle that may also prove useful to other regions facing similar challenges.

Though the paper is of an acceptable standard, the authors may want to consider the following points:

\section{Introduction}

It would be beneficial to provide more details about what conservation planning is and why it is needed, and the complex setting (environmental, socio-economic and political) that characterise the Coral Triangle (see Fidelman et al., 2012 ${ }^{1}$ ). These would help contextualise the challenges identified in the following sections; many (if not most) of the challenges result, to some extent, from the complex nature of large-scale marine areas such as the Coral Triangle.

\section{Planning across governance boundaries}

This section addresses the problem of fit and scale; and would benefit from drawing on the corresponding scholarship (see e.g., Young, O.R., 2002²). The authors may want to consider replacing the heading "Planning across governance boundaries" with "Addressing the problem of fit and scale" or something along these lines.

\section{Conclusions}

It would beneficial to generalise the discussion beyond the Coral Triangle; that is, most of the challenges identified are also true to other regions, particularly large-scale marine regions. Insights from the paper would also be applicable to those regions.

\section{Other comments}

Some of the suggested actions to address the challenges identified are challenges themselves 
(e.g., legal reform, integration across governance levels, institutionalising conservation planning etc.). This is because we live in an increasingly complex world where (borrowing from Dietz et al., $2003^{3}$ ) ideal conditions for governance (and for that matter conservation planning) are increasingly rare. That is, many of the challenges identified in the paper are facts of life; accordingly, the real challenge is to find innovative ways to navigate such challenges.

Last, we address related challenges to the Coral Triangle in a recent article - Fidelman et al., $2014^{4}$ - which the authors may find relevant to this paper.

\section{References}

1. Fidelman $P$, Evans $L$, Fabinyi $M$, Foale $S$, et al.: Governing large-scale marine commons: Contextual challenges in the Coral Triangle. Marine Policy. 2012; 36 (1): $42-53$ Publisher Full Text 2. Young OR: The Institutional Dimensions of Environmental Change. 2002. Reference Source 3. Dietz T, Ostrom E, Stern PC: The Struggle to Govern the Commons. Science. 2003; 302 (5652): 1907-1912 PubMed Abstract | Publisher Full Text

4. Fidelman P, Evans LS, Foale S, Weible C, et al.: Coalition cohesion for regional marine governance: A stakeholder analysis of the Coral Triangle Initiative. Ocean \& Coastal Management. 2014; 95: 117-128 Publisher Full Text

Competing Interests: No competing interests were disclosed.

\section{I confirm that I have read this submission and believe that I have an appropriate level of expertise to confirm that it is of an acceptable scientific standard.}

Reviewer Report 22 April 2014

https://doi.org/10.5256/f1000research.4162.r4520

(C) 2014 Yap H. This is an open access peer review report distributed under the terms of the Creative Commons Attribution License, which permits unrestricted use, distribution, and reproduction in any medium, provided the original work is properly cited.

\section{Helen Yap}

The Marine Science Institute, University of the Philippines, Quezon City, Philippines

This is a well-written paper. It summarizes valuable lessons learned from an extensive, not to mention expensive, conservation effort in a critical biodiversity-rich region of the world, the socalled "coral triangle".

My main comments addressed to the authors would pertain to the major obstacles that conservation initiatives have been confronted with over the decades, leading to very few success stories even to this day. I'm rather surprised they are not mentioned at all in the review.

The real issues, in my own experience, are poverty, human population growth, and corruption (both in the government level, but also in the NGO community). 
Regarding the first issue, grinding poverty in the rural areas that abut coastal resources - not only in the countries of the coral triangle - appears to continue unabated, and is only exacerbated by dwindling natural resources, poor or negligent government, and the negative impacts of climate change (sea surface warming, drought, excessive precipitation, more violent storms). A vicious cycle ensues, as all informed individuals should know; namely, poverty begets more natural resource destruction, which begets more poverty... A desperate family (and there are millions of them) needing to put food on the table will catch the last fish, or fell the last tree, regardless of the best disseminated and best articulated conservation schemes at any level or spatial scale. If the status of biodiversity is to improve in the future, shouldn't this issue be addressed?

Which will probably take the authors to territory where they have little expertise, such as the local and global economic orders with their built-in inequities in terms of trade, fiscal policy, human migration, employment opportunities, etc. Though the term "macroeconomic" was mentioned at least once in the manuscript.

The second issue, that of human population growth, does not need much elaboration because it is a glaring one. However, it does have implications for the success of conservation campaigns, and at least deserves mention.

Finally, the issue of corruption. It's a sensitive one, and I'm not sure the authors wish to tackle it head-on in case there are repercussions from national government or local officials they need to deal with in the course of their work. The matter of corruption within the NGO community I've heard about first-hand, such as the overcharging for boat use that is then passed on to the donors. Should such facts be taken into consideration when voicing concern about the success of conservation efforts in the long-term and, with them, the well-being of local human populations (e.g. "livelihoods") that they are supposed to help ensure?

As a minor comment, the paper might benefit from some graphs and other figures.

Competing Interests: No competing interests were disclosed.

\section{I confirm that I have read this submission and believe that I have an appropriate level of expertise to confirm that it is of an acceptable scientific standard, however I have significant reservations, as outlined above.}

Author Response 13 May 2014

\section{Rebecca Weeks}

Many thanks for your review Helen.

The issues that you raise - poverty, human population growth, and corruption - are certainly major obstacles to effective conservation of biodiversity, in the Coral Triangle and elsewhere.

Our aim with this manuscript was to highlight challenges specific to conservation planning, as opposed to those facing conservation initiatives more generally. This narrower focus led 
to our identification of ten challenges that are more directly related to the uptake and application of conservation planning and, we hope, more easily resolved through action by researchers and conservation practitioners, than the ones you mention.

Of course, the context within which conservation planning is undertaken would be improved through efforts to resolve wider issues relating to poverty, population growth and corruption, and this warrants mention here.

In revision, we will both clarify the scope of the manuscript better, and include mention of the overarching challenges of population, poverty, and corruption. Please note though that we will await a second peer review report before revising our manuscript.

Competing Interests: No competing interests were disclosed.

The benefits of publishing with F1000Research:

- Your article is published within days, with no editorial bias

- You can publish traditional articles, null/negative results, case reports, data notes and more

- The peer review process is transparent and collaborative

- Your article is indexed in PubMed after passing peer review

- Dedicated customer support at every stage

For pre-submission enquiries, contact research@f1000.com 